\title{
Examination of Primary School Students' Exam Success in terms of Controllable Variables by Logistic Regression Analysis
}

\author{
Mehmet Ali Yarım $\bowtie 1$ \& Işıl Bedirhanoğlu2 \\ 1,2 Ministry of Education, Erzurum, Turkey \\ $\bowtie$ karazeybekli@hotmail.com
}

\begin{abstract}
This descriptive research using the relational screening model aims at examining the controllable variables that affect students' exam success. In this research, the problems of whether the time spent by the students with their families, having a study desk or room at home, having a library at home and the time spent on digital screens affect student success. The research study group consists of third- and fourth-grade students from 20 primary schools in various provinces of Turkey, selected by a convenient sampling method in the years 2020-2021. Variables with the achievement evaluation exam were prepared by the field teachers for the student's exam scores and controlled by the expert teachers. The data obtained in the research were analyzed assisted by the SPSS program with descriptive and logistic regression analysis. The research results concluded that students who have a room or a desk at home, have a library at home, spend quality time at home with their family in the evenings, and feel happy at home can increase student success in primary schools.
\end{abstract}

Keywords: Exam success, number of books at home, student success, logistic regression, socioeconomic level, primary school

How to Cite: Yarım, M., \& Bedirhanoğlu, I. (2021). Examination of Primary School Students' Exam Success in terms of Controllable Variables by Logistic Regression Analysis. Mimbar Sekolah Dasar, 8(3), $233-249$. doi:https://doi.org/10.53400/mimbar-sd.v8i3.37954.

INTRODUCTION The most critical potential capital in the development and progress of a country is human capital. Institutions that transform this capital into power are educational institutions. The characteristics of today's human power are qualities such as scientific thinking skills, productivity, creativity, and problem-solving skills. Searching for ways to give individuals these characteristics is an essential condition of success. When considered in terms of schools, student success is significant in activating the potential power of the country. The guarantee of the future of the country and sustainable development is related to increasing the current success and performance of today's students.

Student success is naturally considered a critical element for many researchers and educators. For this reason, many studies are trying to analyze the variables affecting this situation in depth. The concept of student success is evaluated as the academic equivalent of the acquired knowledge and skills based on the performance in the courses taught in schools, the grades obtained by the students from the teacher taught at the school, various exams, and test scores (Sarier, 2016). The learning process is associated with success, which affects all people and children (Kubiatko et al., 2018). Differences in academic success in exams of students from the 
Mehmet Ali Yarım \& Işıl Bedirhanoğlu, Examination of Primary School Students' Exam Success in Terms of...

same school, who study in the same courses with the same methods, trigger many researchers to research to determine the reasons for this situation and the factors affecting success (Darling-Hammond, 1999).

The main task of the education system in a country is to increase students' academic performance and success and ensure their professional development. In this context, all education systems in various countries define improving students' academic achievement as their primary goal. Many studies discussed exam and academic success factors, including personal and family characteristics, qualities, work habits, anxiety disorders, leisure activities, motivation, emotional differences, gender, mental, teacher, and school qualifications. These factors are believed to affect success (Gamazo \& Martinez Abad, 2020; Dinkelmann \& Buff, 2016; Arıcı, 2007; Lee, 2016; Balentyne \& Varga, 2017; Şevik, 2014; Kalaycıoğlu, 2015; Wang, 2004; Yao et al., 2015; Damrongpanit, 2019; Polat, 2009; Özer \& Anıl, 2011; Dağdelen, 2013; Dadll, 2015; Rodríguez-Santero \& Gil-Flores, 2018). Klomegah, 2007. Factors in the student context are among the most studied variables in achievement research. Factors such as socioeconomic condition, immigration, gender, age/class, participation in early childhood education, or grade retention have been consistently proven to be highly correlated with student performance (Karakolidis et al., 2016; Pholphirul, 2016; Gamazo et al., 2018; AsensioMuñoz et al., 2018).

With the emergence of large-scale assessments in recent years, large databases of various types of variables (student performance and history, school practices and processes, family structure, etc.) have been consistently provided to education researchers. Studies conducted by organizations such as the Program for International Student Assessment (PISA) from the Organization for Cooperation and Economic Development (OECD), or Trends in the Study of International Mathematics and Science (TIMSS), and the International Study of Literacy Studies (PIRLS), International Association for the Assessment of Educational Achievement (IEA) has had a remarkable impact on the development of educational research in recent years (Gamazo et al., 2018). In addition to measuring the student's academic success, several variables that affect this success are also included in the high-level exam content.

According to the PISA results in 2012, 2015 and 2018, variables affecting student performance in the Turkish sample include fairness and effectiveness in educational resources, school resources, socio-economic level, pre-school education period, educational background, gender, motivation, self-efficacy, school income, reading habits, and emotional support of the family. These variables are based on the factors such as the number of mathematics teachers and the number of students in the school, computer usage opportunities, the mother's working status, having a computer at home, the students having a room of their own, and the number 
of books at home (Acar \& Öğretmen; 2012; Özer-Özkan \& Acar-Güvendir, 2014; Aksu et al., 2017; Ertem, 2021; Türkan et al., 2015; Arıcı \& Altıntaş, 2014; Güzeller \& Şeker, 2016).

Examining the variables associated with student performance has historically been vital in educational research. The research conducted by Coleman and friends (1966) focused on the central role of socio-economic variables in student achievement. For ten days, their discussions on the effect of various individual and demographic variables on achievement had increasingly continued. Unfortunately, it did not seem possible to correct some of the variables discussed in these discussions and thought to be influential in student success quickly. Variables such as the socio-economic structure of the family, the number of siblings at home, and the cultural structure of the family are factors that would not change from evening to morning. However, several variables affected the student's success in the exam but could be controlled quickly with minimal cost, even just by creating awareness. The investigation relating to the origin of variables, whether from the student, parent, and place of residence, and the effects of these variables on student success in different geographies and levels would provide essential parameters in terms of administrative mind, educational goal, problem, and innovative strategy; and would provide meaningful, explanatory and guiding data to practitioners in routine actions. In addition, the fact that these variables are controllable will provide the opportunity to get results quickly in the short and medium-term, both for parents who want to increase their children's success and for administrators who aim to ensure quality and equal opportunity in education. In this research, the relationship between the student, which is thought to be influential in student success, the controllable variables in the house where he lives, and the students' exam success was examined. The novelty of this research will bring to the field is that it tries to determine how easily changeable and controllable variables (time spent with the family, creating a library at home, creating a study desk at home, reducing the time spent on digital screens) affect student success at different socio-economic levels. For this primary purpose, answers to the following questions were sought in the research.

1. Is having a room or a study desk in the house where the student lives connected to the success of the exam?

2. Is having a library in the house where the student lives connected to the success of the exam?

3. Is the fact that the student often sees his parents reading at home connected to the success of the exam?

4. Is the time a student spends on digital screen devices such as tablets, TVs, and phones in a day connected to the success of the exam?

5. Is the time a student spends his evenings alone or with his family connected to the success of the exam? 
Mehmet Ali Yarım \& Işıl Bedirhanoğlu, Examination of Primary School Students' Exam Success in Terms of...

6. Is the free time that a student spends on tablets, phones, etc. connected to the success of the exam?

7. Is the student's general feeling of happiness at home connected to the success of the exam?

\section{METHOD}

This research was designed in a descriptive-relational survey model. The purpose of this research design is to describe a situation or event as it exists and to determine its relationship, interaction, and level with the variables thought to cause this situation (Kaya et al., 2012). An exam including demographic variables and acquisition questions was conducted for the participants to answer in the research. The exam questions prepared by eight classroom teachers who are experts in their fields were made online and simultaneously on 28 April 2021 with the participation of volunteer students.

\section{Working Group}

The research study group consists of third- and fourth-grade students from 20 primary schools in various provinces of Turkey (Erzurum, İzmir, Bursa, Ankara, Rize, İstanbul, Mersin, Batman). They were selected with a convenient sampling method in the 2020-2021 academic year. These provinces, which are in seven geographical regions of Turkey, were chosen because they represent the socio-economic and cultural structure of the regions well. Due to the limitations in terms of time, money, and labor in this sampling method, the sample can be selected from easily accessible and functional units (Büyüköztürk et al., 2015).

Table 1. Descriptive Statistics of Participants

\begin{tabular}{|c|c|c|c|}
\hline & & $\mathbf{N}$ & $\%$ \\
\hline \multirow[t]{3}{*}{ Gender } & Female & 611 & 60.3 \\
\hline & Male & 401 & 39.7 \\
\hline & Total & 1012 & 100 \\
\hline \multirow[t]{3}{*}{ Grade } & Third-grade & 630 & 63 \\
\hline & Fourth-grade & 382 & 37 \\
\hline & Total & 1012 & 100 \\
\hline \multirow[t]{7}{*}{ Province } & Erzurum & 259 & 25.59 \\
\hline & Bursa & 174 & 17.19 \\
\hline & Izmir & 146 & 14.42 \\
\hline & Istanbul & 123 & 17.8 \\
\hline & Ankara & 105 & 12.15 \\
\hline & Mersin & 80 & 7.90 \\
\hline & Rize & 75 & 7.41 \\
\hline
\end{tabular}




Batman $\quad 50 \quad 4.94$

Based on Table 1, the participants in this research consisted of 611 female students (60\%), and 401 male students (40\%). The number of 3rd-grade students (630) participating in the research is more than 4th-grade students (382). The survey included 259 students from Erzurum (25.5\%), 174 students from Bursa (17\%), 146 students from İzmir (14\%), 123 students from istanbul (17\%), 105 students from Ankara (12\%), 80 students from Mersin (8\%), 75 students from Rize (7\%), and 50 students from Batman (5\%).

\section{Data Collection Tools}

Within the scope of the research, a form consisting of two parts and prepared online (Google Form) was used to collect data from the students. In the first part, questionnaire forms relating to student variables regarding their demographics and home environment were distributed. In the second part, the questions regarding the evaluation of the exam results prepared by a group of 10 classroom teachers and controlled by a group of 10 teachers were shared online with school principals and classroom teachers. It was held online and simultaneously on 28 April 2021 with the participation of volunteer students.

\section{Data Analysis}

The data obtained from the applied questionnaire were analyzed using the SPSS 22 program. First, exam scores obtained from the questionnaire to determine the factors affecting students' exam success were analyzed in the context of two groups as high level (70 points and above) and low level (0-69 points). First of all, exam scores regarding the predictive variables were analyzed descriptively using arithmetic averages. Then, the relationship between predictive variables and exam scores was evaluated with logistic regression analysis. In this way, students with high test scores and low scores were classified according to the predictive variables.

\section{RESULTS}

In this section, the findings obtained from the data analysis were given. Firstly, descriptive statistics of exam score averages on various variables were examined.

Table 2. Exam Score Averages of Independent Variables

\begin{tabular}{llll}
\hline Variables & Categories & $\mathbf{N}$ & $\begin{array}{l}\text { Exam } \\
\text { Score } \\
\end{array}$ \\
& & & Average \\
\hline Do you have your own room or desk at & Yes & 819 & 78.09 \\
home? & No & 193 & 63.12 \\
\hline Do you have a library at home? & Yes & 815 & 75.36 \\
& No & 197 & 62.33 \\
\hline
\end{tabular}


Mehmet Ali Yarım \& Işıl Bedirhanoğlu, Examination of Primary School Students' Exam Success in Terms of...

\begin{tabular}{llll}
\hline $\begin{array}{l}\text { Do you often see your parents reading } \\
\text { at home? }\end{array}$ & Yes & 422 & 72.85 \\
\hline How much time do you spend with TV, & 1-4 hours & 590 & 61.53 \\
tablet, phone, and internet in a day? & More than 5 hours & 121 & 62.75 \\
\hline How do you spend your evenings at & With my family & 933 & 72.41 \\
\cline { 2 - 4 } home? & Alone & 79 & 61.58 \\
\hline What do you like to do in your spare & Playing with my friends & 552 & 71.77 \\
time? & Playing tablet etc. & 460 & 69.58 \\
\hline Are you happy at home? & Yes & 959 & 73.54 \\
& No & 53 & 54.81
\end{tabular}

Based on the exam score average in Table 2, the students who have their room or desk at home had the highest average score $(=78.09)$, while the students who do not have this opportunity at home had an average score of 63.12. Additionally, the number of students who have a library in their home had the highest average score ( $=75.36)$, compared to the students who do not have a library In their home with an average score of 62.33. Meanwhile, the students who see their parents frequently reading at home $(=72.85)$ had the highest average score than the other group ( =61.53).

In Table 2, there is a relationship between the time spent in front of digital screens during the day and the success of the exam with the highest average score of 77.12. Meanwhile, the students who spend more than 5 hours in front of a digital screen also had the lowest average score. Exam success of students who spend time with their families in the evenings ( =72.41) was higher than students who spend time alone ( =61.58). Exam scores of students who spend their free time playing with their friends and students who spend time with tablets and similar devices were close to each other. The variable of the students' happiness at home had a relatively highest average score ( $=73.54)$ compared to those who said no ( $=54.81)$. In the context of these findings, it can be commented that students who have some advantages in the home environment experience the positive effects of these advantages in the exams.

The descriptive statistics of exam success on demographic variables, the stages of the logistic regression analysis are presented below. Omnibus and Hosmer Lemeshow tests were carried out for the fit values of the model.

Table 3. Omnibus Test for Model Coefficients

\begin{tabular}{llll}
\hline Step & $\mathbf{x}^{2}$ & sd & $\mathbf{P}$ \\
\hline Step & 80.62 & 7 & .000 \\
Block & 80.62 & 7 & .000 \\
model & 80.62 & 7 & .000 \\
\hline
\end{tabular}


Based on Table 3, the p values of the model chi-square value were significant. The significance of this value indicated the existence of a relationship between the predictor variables and the predicted variable (Çokluk et al., 2016).

Table 4. Hosmer and Lemeshow test

\begin{tabular}{llll}
\hline Step & $\mathbf{X}^{2}$ & sd & $\mathbf{P}$ \\
\hline $\mathbf{1}$ & 2.812 & 6 & .832
\end{tabular}

Table 4 shows that the Hosmer and Lemeshow test result was not significant $(p>, 05)$. The insignificance of this value indicated that the model-data fit was sufficient (Çokluk et al., 2016). In this context, the model-data fit was achieved. In the next step, the correct prediction percentage of the model was examined.

Table 5. Correct Classification Percentage of the Logistic Regression Model

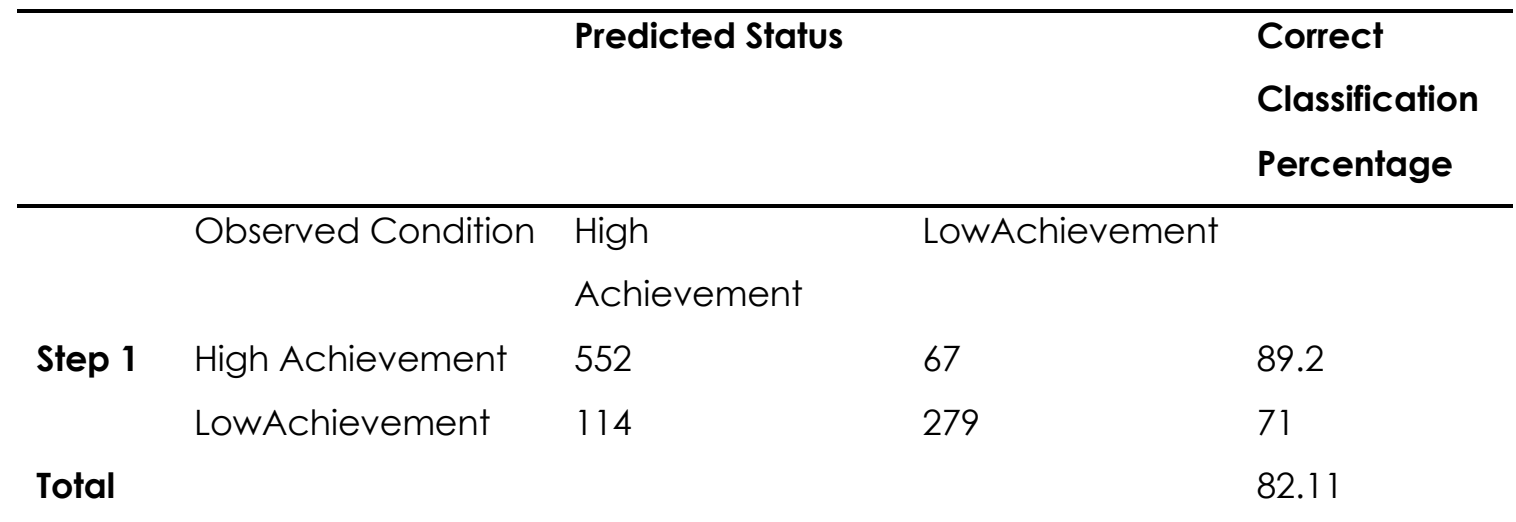

Based on Table 5 with the classification made according to the predictive variables, 552 out of 621 students with high exam success were classified correctly, while 67 were classified incorrectly, thus the rate of correct classification was $89 \%$. On the other hand, out of 393 students with low test success, 279 were classified correctly, and 114 were classified incorrectly. Therefore, the established logistic regression model correctly predicted the exam success score frequency of $831(82.11 \%)$ out of 1012 students observed. Although the established ordinal logistic regression model was meaningful, it was necessary to provide the assumption of parallelism between the categories in order to use this model.

Table 6. Parallelism Assumption Test

\begin{tabular}{llccc}
\hline Model & $\mathbf{- 2}$ Log Likelihood & $\mathbf{X}^{\mathbf{2}}$ & sd & Possibility \\
\hline 127.405 & 81 & 51 & .104 \\
\hline In Table.6, the regression coefficients were equal in all categories of the dependent variable, \\
and the assumption of parallelism was fulfilled. Therefore, after this stage, parameter \\
estimations, significance tests, and odds ratios in the last column were given below.
\end{tabular}

Table 7. Coefficient Estimates of Intended Model Variables 
Mehmet Ali Yarım \& Işıl Bedirhanoğlu, Examination of Primary School Students' Exam Success in Terms of...

\begin{tabular}{llllllll}
\hline Step & & beta & $\mathbf{s}$ & wald & $\mathbf{s d}$ & $\mathbf{p}$ & Exp(beta) \\
\hline $\mathbf{1}$ & $\begin{array}{l}\text { Do you have your own room or } \\
\text { desk at home? }\end{array}$ & -.535 & .171 & 9.791 & 1 & .002 & .586
\end{tabular}

Do you have a library at home?

$\begin{array}{llllll}-.675 & .172 & 15.391 & 1 & .000 & .509\end{array}$

Do you often see your parents

$\begin{array}{lllllll}\text { reading at home? } & -.176 & .139 & 1.609 & 1 & .205 & .838\end{array}$

How much time do you spend at

$\begin{array}{lllllll}\text { home with TV, tablet, phone, and } & -.036 & .214 & .029 & 1 & .865 & .964\end{array}$

internet

How do you spend your evenings

at home?

$\begin{array}{llllll}-.986 & .9252 & 15.281 & 1 & .000 & .373\end{array}$

What do you like to do in your

spare time?

$\begin{array}{llllll}-.092 & .095 & .403 & 1 & .526 & .912\end{array}$

Are you happy at home

$\begin{array}{llllll}1.487 & .329 & 20.468 & 1 & .000 & .226\end{array}$

$\begin{array}{lllllll}\text { Still } & 2.992 & .457 & 42.777 & 1 & .000 & 19.917\end{array}$

When the variables "Do you have your room or desk at home," "Do you have a library at home?", "How do you spend your evenings at home?", "Are you happy at home and school?" examined, the test variables had a significant effect on the success of the exam. Exponential numbers were significant in determining the size of the relationship in logistic regression analysis because it allowed the change in the predicted variable to be expressed as a percentage, and this percentage was found with the formula [(exponential coefficient-1)*100] (Çokluk et al., 2016). In this context, a positive increase of 1 unit in the predictor of having a room or desk at home affected a $41 \%$ increase in exam success. According to the same table, a positive increase of 1 unit in the predictor of having a library at home affected a $49 \%$ increase in exam success. A one-unit increase in spending time at home in the evening led to a $62 \%$ increase in students' exam scores. Finally, a 1-unit increase in the student's happiness at home predictor affected a $77 \%$ increase in exam success. 


\section{DISCUSSION}

According to the research results, having a room or at least a desk at home affected their exam success due to the highest average scores in the exam compared to another variable. This indicated that the students can create a suitable and orderly study environment because they have their rooms or desks. This environment has a positive effect on both the lessons and the exams. This result is in line with Akhan and Bindak (2017). They concluded that having a study room at home effectively achieves mathematics. In addition, Yenilmez and Duman (2008) found that students with a good working environment at home are more successful than students who do not. According to Savaş and Gürel (2014), the students who have a study room at home and watch TV with limited time are essential variables that determine success, and they also can achieve more successful results.

Another result reached in the research is that students who have a library at home have higher exam success scores. According to this result, the large number of reading books you have at home indicates a significant student's academic development. The development of a brain is directly proportional to the number of different words it has. A brain with more words will process faster and more accurately. Reading habits directly affect our success in the exam by improving our vocabulary and language skills (Tanju, 2010, Güngör, 2009). A student who has the habit of reading will understand and solve a question faster and more accurately (YIImaz, 2016). In this context, it is seen that the students who grow up at home with insufficient accessibility to available books can determine exam success, such as thinking, remembering, analyzing, quick and correct thinking. International studies such as PISA and TIMMS have also revealed the number of books at home in student success. According to PISA results, as the number of books at home increases, student success also increases at the same level (Türkan at. al., 2015). According to TIMMS 2011 results, the number of books students read at home with high exam success is also relatively high (Aydın, 2015). In another study conducted by Sikora on 31 countries and more than 160 thousand participants, having a library at home or having many books is an essential variable in success (Flood, 2018). Moreover, Evans et al. (2014) also found that the number of books at home and reading books is highly effective in student success. In the domestic literature, according to the results of the exam with 28956 participants, consisting of 8th-grade students within the scope of the Ministry of Education (MEB)'s ABIDE program, the average exam score of the students who have less than five books at home is 454 , while the average of the exam score of the students who have more than 80 books at home is 548 (MEB, 2017). In addition, Çiftçi and Çağlar (2014), in their study on high school students, concluded that the socio-economic structure of the family and the number of books read at home have significant effects on the university scores of the students.

Another result of the research is that students who spend time with their families in the evenings have higher exam success. In other words, students who usually spend time alone at home in 
Mehmet Ali Yarım \& Işıl Bedirhanoğlu, Examination of Primary School Students' Exam Success in Terms of...

the evenings cannot show sufficient success in the exams. According to the results of the ABIDE program conducted by the Ministry of National Education in 2016, the exam scores of students who spend more time with their families and receive more attention and support from their families are pretty high (MEB, 2017). According to Özel and Zelyurt (2016), students who have high-quality communication with their parents emphasize positive success outcomes. Dam (2008) found that students who communicate well with their families and spend quality time have high school success.

According to Demiriz and Ulutaş (2016), the level of happiness of children directly affects various temperament characteristics such as perseverance, communication, and rhythmicity. Happy and successful students grow up in happy families. Happy children are successful by learning ways to take responsibility, cope with stress, and ensure their development (Abapischology, 2021). Clinical studies support the idea that those who were happy in childhood are more likely to have strong communication skills, establish healthier relationships, have longer marriages, have higher self-esteem and overall satisfaction with life, as weekend a more successful career in later years (Popomaronis, 2019). In support of the research results, Alkan (2018) in his research on 566 students consisting of eighth and twelfth-grade concluded that the students with their broken families and unhappy students were relatively unsuccessful in education.

When the domestic and foreign literature is examined, many studies are closely related to the current study results that affect the exam success of students. Eskicumalı and Eroğlu (2001) also concluded in their study that the socio-economic structure of the family affects the problemsolving skills of fourth and 5th-graded students. Aydın (2015) found that home education opportunities directly affect the student's exam success. Arslantaş, Özkan and Külekçi (2012) emphasized that the role of income and education level in success is high. In addition, some studies say that the education level of the parents, the resources at home, the income level, the socio-economic structure of the family directly affect the student's success in education and exams (Engin-Demir, 2009; Özdemir \& Gelbal, 2014; Sarıer, 2016; Yelgün \& Karaman, 2015, Akkurt and Köse, 2019, Oral and McGivney, 2013; Ismail and Awang, 2008; Akyüz, 2014; Van Ewijk and Sleegers, 2010; Zhao et al., 2011; Özer and Anı, 2011). Some of these variables (socioeconomic structure of the family, income level, education level of the family, cultural structure) are uncontrollable and cannot change quickly. However, in the current study, the students who have rooms or desks at home, the number of books at home increases, family time at home increases, and limited time spent on a digital screen, can be positively controlled in a short period. In other words, it can be a few small touches to make students feel happy. There are also variables to be corrected in this sense, and these variables are much more effective than expected in students' exam success. Through the positive changes in these variables, the 
students' exam success can be increased. Thus, this can significantly affect the achievement of educational purposes.

\section{CONCLUSION \& SUGGESTIONS}

Exam success is not only related to students' academic qualifications or cognitive characteristics. Many variables affect the student's exam success. Some controllable variables in the student's home environment affect the student's exam success. For example, having a study room or desk at home affects student success positively. Similarly, students who have a library at home have higher exam success. The time students spend with their families at home affects their exam success. Students who chat with their family or play games in the evenings have higher exam success. Students who spend less time on digital screens such as tablets, televisions, and computers at home have higher success. Finally, students who feel happy at home have higher exam success. With the correct management of these controllable and easily changeable variables by families and education administrators, it will be possible to reach individual and national goals in education much more quickly. This study is limited to primary school students. The variables in this study are limited to variables such as the time spent with the family, having a library at home, having a study room or desk, and time spent on digital screens. The success in this study is limited to the achievement exam. The following recommendations are provided to researchers who will study this subject in the future:

- This subject can be studied at other education levels (secondary school, high school, university).

- Student success can be studied with different socio-economic and cultural variables.

- The entire academic year can be monitored to determine student success.

- In order to increase the success of their students, it is recommended that families spend more time with their students, reduce digital screen time at home, provide a study room or desk, and keep as many books as possible at home.

\section{REFERENCES}

Abapischology (2021, May 17). Mutlu aileler başarılı çocuklar [Happy families are successful children]. https://abapsych.com/mutlu-aileler-basarili-cocuklar-yetistiriyor

Acar, T., \& Öğretmen, T. (2012). Analysis of 2006 PISA science performance via multilevel statistical methods. Education and Science, 37(163), 178-189.

Akhan, S. \& Bindak, R. (2017). Bazı kişisel değişkenlerin ortaokul öğrencilerinin matematik başarısı üzerindeki etkisi: bir regresyon modeli [The effect of some personal variables on middle school students' mathematics achievement: a regression model]. Ihlara Journal of Education, 2(2), 05-17. Retrieved from http://ihead.aksaray.edu.tr/tr/pub/issue/33690/373497 
Mehmet Ali Yarım \& Işıl Bedirhanoğlu, Examination of Primary School Students' Exam Success in Terms of...

Akkurt, Z. \& Köse, E. (2019). Öğrenci başarısının okul, öğretmen ve aileyle ilgili değişkenler açısından incelenmesi [Examining student achievement in terms of school, teacher and family related variables]. Pamukkale University Journal of Education Faculty, 47(1), 1-16. http://dx.doi.org/10.9779/pavefd.451853

Aksu, G., Guzeller, C. O. \& Eser, M. T. (2017). Analysis of maths literacy performances of students with hierarchical linear modeling (hlm): The case of PISA 2012 Turkey. Education and Science, 42(191), 247-266. http://dx.doi.org/10.15390/EB.2017.6956

Akyüz, G. (2014). TIMSS 2011 'de öğrenci ve okul faktörlerinin matematik başarısına etkisi [The effect of student and school factors on mathematics achievement in TIMSS 2011]. Education and Science, 39(172), 153-162.

Alkan, E. O. (2018). Aile parçalanmasının çocuğun okul başarısına etkisi: Trabzon örneği [The effect of family disintegration on the school success of the child: The case of Trabzon]. Black Sea Research Institute Journal, 4(5), 167-225. http://dx.doi.org/10.31765/karen.438376

Arıcı, I. (2007). Illköğretim din kültürü ve ahlak bilgisi dersinde öğrenci başarııını etkileyen faktörler (Ankara örneği) [Factors affecting student success in primary school religious culture and ethics course (Ankara example)]. Doctoral Thesis. Ankara University, Ankara.

ArıcI, O. \& Altintas, O. (2014). An investigation of the PISA 2009 reading literacy in terms of socioeconomical backgrounds and receiving pre-school education "Turkey Example". Ankara University, Journal of Faculty of Educational Sciences, 47(1), 423-448. http://dx.doi.org/10.1501/Egifak_0000001333

Arslantaş, H., Özkan, M. \& Külekçi, E. (2012). Eğitim fakültesi öğrencilerinin akademik başarı düzeylerinin bazı demografik değişkenler açısından incelenmesi [Investigation of academic achievement levels of education faculty students in terms of some demographic variables]. Electronic Journal of Social Sciences, 11 (39), 395-4.

Asensio-Muñoz, I., Carpintero-Molina, E., Expósito, E. \& Lopez-Martin, E. (2018). How much gold is in the sand? Data mining with Spain's PISA 2015 results. Revista Española de Pedagogía, 76 (270),225-245. https://doi.org/ 10.22550/REP76-2-2018- 02.

Aydin, M. (2015). Öğrenci ve okul kaynaklı faktörlerin TIMSS matematik başarısına etkisi [The effect of student and school related factors on TIMSS mathematics achievement]. Master's Thesis. Necmettin Erbakan University, Konya.

Balentyne, P. \& Varga, M. A. (2017). Attitudes and achievement in a self-paced blended Mathematics Course. Journal of Online Learning Research, 3(1), 55-72. 
Büyüköztürk, Ş., Çakmak, E. K., Akgün, Ö. E., Karadeniz, S., and Demirel, F. (2015). Bilimsel araştırma yöntemleri [Scientific research methods]. Ankara: Pegem Academy.

Çiftci, C., \& Çaglar, C. (2014). Ailelerin sosyo-ekonomik özelliklerinin öğrenci başarısı üzerindeki etkisi: Fakirlik kader midir? [The effect of families' socio-economic characteristics on student achievement: Is poverty destiny?]. International Journal of Human Sciences, $11(2), \quad$ 155-175. Retrieved from https://www.jhumansciences.com/ojs/index.php/IJHS/article/view/2914

Çokluk, Ö., Şekercioğlu, G., \& Büyüköztürk, Ş. (2016). Sosyal Bilimler için çok değişkenli istatistikte SPSS ve LISREL Uygulamaları [Applications of SPSS and LISREL in multivariate statistics for Social Sciences]. Ankara: Pegem Academy.

Coleman, J. S., Campbell, E. Q., Hobson, C. J., McPartland, J., Mood, A. M., Weinfeld, F. D. \& York, R. L. (1966). Equality of educational opportunity. Washington DC: Government Printing Office.

Dadlı, G. (2015). Ortaokul 8. Sınıf öğrencilerinin fen ve teknoloji dersine yönelik öz düzenleme becerileri ve öz yeterlikleri ile akademik başarıları arasındaki ilişkinin incelenmesi [Examining the relationship between secondary school 8th grade students' self-regulation skills and self-efficacy for science and technology lesson and their academic achievement]. Master's Thesis. Kahramanmaras Sutcu Imam University, Kahramanmaras.

Dağdelen, S. (2013). Biyoloji derslerinde öğretmenlerin kişilerarası davranışı, sınıf öğrenme ortamı ve öğrenci başarısı arasındaki ilişkinin incelenmesi [Examining the relationship between teachers' interpersonal behavior, classroom learning environment and student achievement in biology lessons]. Master's Thesis, Marmara University, Istanbul.

Dam, H. (2019). Öğrencinin okul başarısında aile faktörü [Family factor in student's school success]. Hitit University Faculty of Theology Journal, 7(14), 75-99.

Damrongpanit, S. (2019). From modern teaching to mathematics achievement: The mediating role of mathematics attitude, achievement motivation, and self-efficacy. European Journal of Educational Research, 8(3), 713-727. http://dx.doi.org/10.12973/eu-jer.8.3.713

Darling-Hammond, L. (1999). Teacher quality and student achievement: a review of state policy evidence. University Of Washington: Center for the Study of Teaching and Policy

Demiriz, S. \& Ulutaş, I. (2016). Çocuklar ne kadar mutlu? Bazı değişkenlere göre çocuklarda mutluluğun belirlenmesi [How happy are the children? Determination of happiness in children according to some variables]. Adnan Menderes University Faculty of Education 
Mehmet Ali Yarım \& Işıl Bedirhanoğlu, Examination of Primary School Students' Exam Success in Terms of...

Journal of Educational Sciences, 7(1), 16-24. Retrieved from https://dergipark.org.tr/tr/pub/aduefebder/issue/33906/37531

Dinkelmann, I., \& Buff, A. (2016). Children's and parents' perceptions of parental support and their effects on children's achievement motivation and achievement in mathematics. A longitudinal predictive mediation model. Learning and Individual Differences, 50, 122 132. http://dx.doi.org/10.1016/j.lindif.2016.06.029

Engin-Demir, C. (2009). Factors influencing the academic achievement of the Turkish urban poor. International Journal of Educational Development, 29(1), 17-29. http://dx.doi.org/10.1016/j.ijedudev.2008.03.003

Ertem, H. Y. (2021). Examination of Turkey's PISA 2018 reading literacy scores within studentlevel and school-level variables. Participatory Educational Research, 8(1), 248-264. http://dx.doi.org/10.17275/per.21.14.8.1

Eskicumalı, A., \& Eroğlu, E. (2014). Ailenin sosyo-ekonomik ve eğitim düzeyleri ile çocukların problem çözme yetenekleri arasındaki ilişki [The relationship between the socioeconomic and educational levels of the family and the problem-solving abilities of children]. Sakarya University Faculty of Education Journal 0 (1), 165-189. Retrieved from https://dergipark.org.tr/tr/pub/sakaefd/issue/11223/134005

Evans, M., Kelley, J., \& Sikora, J. (2014). Scholarly culture and academic performance in 42 nations. Social Forces, 92(4), 1573-1605. http://dx.doi.org/10.1093/sf/sou030

Flood, A. (2018, October 10). Growing up in a house full of books is major boost to literacy and numeracy, study finds. https://www.theguardian.com/books/2018/oct/10/growing-upin-a-house-full-of-books-is-major-boost-to-literacy-and-numeracy-study-finds

Gamazo, A. \& Martínez Abad, F. (2020). An exploration of factors linked to academic performance in pisa 2018 through data mining techniques. Frontiers in Psychology, 11 (1), 1-17. https://doi.org/10.3389/fpsyg.2020.575167

Gamazo, A., Martínez-Abad, F., Olmos-Migueláñez, S., \& Rodríguez-Conde, M. J. (2018). Assessment of factors related to school effectiveness in PISA 2015.A Multilevel Analysis. Revista de Education, 379(1), 56-84.

Güngör, E. (2009). Investigation of the relationship between the reading habits of primary school 5th grade students and their academic achievement in turkish lessons. Master Thesis. Cukurova University, Adana. 
Güzeller, C. O. \& Şeker, F. (2016). Variables associated with students' science achievement in the programme for international student assessment (PISA 2009).Necatibey Faculty of Education Electronic Journal of Science and Mathematics Education, 10(2), 1-20. http://dx.doi.org/10.17522/balikesirnef.273863

Ismail, N. A. \& Awang, H., (2008), Differentials in mathematics achievement among eighthgrade students in Malaysia. International Journal of Science and Mathematics Education, 6(1), 559-571. http://dx.doi.org/10.1007/s10763-007-9109-4

Kalaycioglu, D. B. (2015). The influence of socio-economic status, self-efficacy, and anxiety on mathematics achievement in England, Greece, Hong Kong, the Netherlands, Turkey, and the USA. Educational Sciences: Theory and Practice, 15(5), 1391-1401. http://dx.doi.org/10.12738/estp.2015.5.2731

Karakolidis, A., Pitsia, V., \& Emvalotis, A. (2016). Examining students' achievement in mathematics: A multilevel analysis of the Programme for International Student Assessment (PISA) 2012 data for Greece. International Journal of Educational Research, 79, 106-115. http://dx.doi.org/10.1016/j.ijer.2016.05.013

Kaya, A., Balay, R., \& Göçen, A. (2012). The level of teachers' knowing, application and training need on alternative assessment and evaluation techniques. Journal of Human Sciences, 9(2), 1229-1259. https://www.j-humansciences.com/ojs/index.php/IJHS/article/view/2272

Klomegah, R. Y. (2007). Predictors of academic performance of university students: an application of the goal efficacy model. College Student Journal, 41 (2), 407-415.

Kubiatko, M., Grecmanova, H., Balatova, K., Urbanovska, E., \& Cabanova, V. (2018). Validity and reliability analyses for the climate of science subjects research tool. Open Access Journal of Science, 2(1). 259-263. http://dx.doi.org/10.15406/oajs.2018.02.00084

Lee, J. (2016). Attitude toward school does not predict academic achievement. Learning and Individual Differences, 52(1), 1-9. http://dx.doi.org/10.1016/j.lindif.2016.09

Mınıstry Of Educatıon [MEB] (2017). Akademik becerilerin izlenmesi ve değerlendirilmesi [Monitoring and evaluation of academic skills]. Ankara: Mınıstry Of Educatıon Assessment, Evaluation And Exam General Directorate Of Services.

Oral, I. \& McGivney, E. (2013). Türkiye'de matematik ve fen bilimleri alanlarında öğrenci performansı ve başarının belirleyicileri TIMSS 2011 analizi [TIMSS 2011 analysis of student performance and determinants of success in mathematics and science in Turkey]. Istanbul: Education Reform Initiative Analysis Report. 
Mehmet Ali Yarım \& Işıl Bedirhanoğlu, Examination of Primary School Students' Exam Success in Terms of...

Özdemir, B. \& Gelbal, S. (2014). PISA 2009 sonuçlarına göre öğrenci başarısını etkileyen faktörlerin kanonik ortak etki analizi ile incelenmesi [Analyzing the factors affecting student achievement according to PISA 2009 results with canonical joint effect analysis]. Education and Science, 39(175), 41-57.

Özel, E \& Zelyurt, H. (2016). Anne baba eğitiminin aile çocuk ilişkilerine etkisi [The effect of parent education on family-child relationships]. Journal of Social Policy Studies, 36(1), 9-34. http://dx.doi.org/10.21560/spcd.60151

Özer, Y. \& Anil, D. (201 1). Öğrencilerin fen ve matematik başarılarını etkileyen faktörlerin yapısal eşitlik modeli ile incelenmesi [Examination of the factors affecting students' science and mathematics achievement with the structural equation model]. Hacettepe University Faculty of Education Journal, 41 (1), 313-324.

Özer-Özkan, Y. \& Acar-Güvendir, M. (2014). Socio-economic factors of students' relation to mathematic achievement: comparison of PISA and ÖBBS. International Online Journal of Educational Sciences, 6(3), 776-789. http://dx.doi.org/10.15345/iojes.2014.03.020

Pholphirul, P. (2016). Pre-primary education and long-term education performance: Evidence from Programme for International Student Assessment (PISA) Thailand. Journal of Early Childhood Research, 15(4), 410-431. https://doi.org/10.1177/1476718X15616834

Polat, S. (2009). [Akademik başarısızlığın toplumsal eşitsizlik temelinde çözümlenmesi] Analyzing academic failure on the basis of social inequality. Education Science Society Journal, $7(25), 46-61$.

Popomaronis, T. (2019, April 5). Want to raise successful kids? Harvard, MIT study says doing one thing at age 4 could make them happier and wealthier in life. https://www.cnbc.com/2019/04/05/harvard-mit-study-says-parents-do-this-one-thingto-raise-happier-successful-wealthier-children.html

Rodríguez-Santero, J., \& Gil-Flores, J. (2018). Contextual variables associatedwith differences in educational performance between european union countries. Culturel Education. 30(1), 605-632. : https://doi.org/10.1080/11356405.2018.1522024

Sarıer, Y. (2016). Türkiye' de öğrencilerin akademik başarısını etkileyen faktörler: Bir meta-analiz çalışması [Factors affecting the academic success of students in Turkey: A meta-analysis study]. Hacettepe University Faculty of Education Journal, 31(3), 609-627. http://dx.doi.org/10.16986/HUJE.2016015868

Savaş, B. \& Gürel, R. (2014). The variables affecting the success of students. Educational Research and Reviews, 9(1), 41-50. http://dx.doi.org/10.5897/ERR2013.1639 
Şevik, Y. (2014). Illköğretim müdür ve müdür yardımcılarının öğrencilerin akademik başarııını etkileyen faktörlere ilişkin görüşleri ile akademik başarısına katkıları [The views of primary school principals and vice principals on the factors affecting the academic success of students and their contributions to their academic success]. Master's Thesis. Mehmet Akif Ersoy University, Burdur.

Tanju, E. H. (2010). Çocuklarda Okuma Alıskanlıklarına Genel Bir Bakış [An Overview of Reading Habits in Children]. Family and Society, 6(22), 30-39.

Türkan, A., Üner, S. S., \& Alcı, B. (2015). 2012 PISA matematik testi puanlarının bazı değişkenler açısından incelenmesi [Examination of 2012 PISA math test scores in terms of some variables]. Aegean Journal of Education, 16(2),358-372.

Van Ewijk, R., \& Sleegers, P. (2010). The effect of peer socio-economic status on student achievement: A meta-analysis. Educational Research Review, 5(2), 134-150. http://dx.doi.org/10.2139/ssrn.1402645

Wang, D. B. (2004). Family background factors and mathematics success: A comparison of Chinese and US students. International Journal of Educational Research, 41 (1), 40-54.

Yao, G., Zhimin, L., \& Peng, F. (2015). The effect of family capital on the academic performance of college students-a survey at 20 higher education institutions in Jiangsu Province. China Education Social. 48(1), 81-91. http://dx.doi.org/10.1080/10611932.2015.1014713

Yelgün, A. \& Karaman, ì. (2015). Düşük sosyoekonomik düzeydeki mahallede bulunan bir Ilköğretim okulunda akademik başarıyı düşüren faktörler nelerdir [What are the factors that decrease academic achievement in a primary school located in a low socioeconomic neighborhood?]. Education and Science, 40(179), 259-268. http://dx.doi.org/10.15390/EB.2015.2331

Yenilmez, K., \& Duman, A. (2008). İlköğretimde matematik başarısını etkileyen faktörlere ilişkin öğrenci görüşleri [Student views on the factors affecting mathematics achievement in primary education]. Manas Journal of Social Sciences, 19, 251-268.

Yılmaz, B. (2016, January 31). Okuma alışkanlığının sınav başarısına etkisi [The effect of reading habits on exam success]. https://bulentyilmazblog.wordpress.com/2016/01/31/okumaaliskanliginin-sinav-basarisina-etkisi/

Zhao, N., Valcke, M., Desoete, A., Verhaeghe, J., \& XU, K. (2011). A multilevel analysis on predicting mathematics performance in Chinese primary schools: Implications for practice. Asia-Pacific Education Researcher, 20(3), 503-520. 